\title{
A STUDY ON HIGHER SECONDARY STUDENTS' EMOTIONAL MATURITY AND ACHIEVEMENT IN ECONOMICS IN TIRUNELVELI DISTRICT
}

\author{
M.Rajakumar \\ Assistant Professor \\ Department of Education \\ Directorate of Distance Education \\ Annamalai University \\ Annamalai Nagar
}

\begin{abstract}
The aim of this study is to find out the Emotional Maturity and Achievement in Economics of higher secondary students in Tirunelveli District. 1060 Higher secondary students were taken as sample. The tool used to find out the Emotional Maturity is constructed and standardized by Emotional Maturity Scale Constructed and Validated by K.M.Roma Pal (1984). The Academic achievement in Economics was found out using the tool constructed by the investigator. The mean value of Emotional Maturity scores (136.53) indicates that the higher secondary students are having extremely unstable Emotional Maturity, The mean value of Achievement in Economics scores $(M=75.47)$ indicates that the higher secondary students are having high Achievement in Economics. There is significant difference between male and female, Day scholar and Hostel staying Higher Secondary students with respect to their Emotional Maturity. There is no significant difference between rural and urban, Government and Aided Higher Secondary school students with respect to their Emotional Maturity. There is significant difference between male and female Higher Secondary students with respect to their Achievement in Economics. There is no significant difference between rural and urban, Day scholar and Hostel staying, Government and Aided Higher Secondary school students with respect to their Achievement in Economics.
\end{abstract}

\section{INTRODUCTION:}

Emotional maturity is the result of healthy emotional development. The term Emotional maturity essentials involves emotional control According to this view the emotionally mature person, is able to hide his feelings such a person is not subject to swings in mood and can suffer in silence. When he does express emotion, he does so with moderation, decently and in good order.

An emotionally matured person is the one who can give expression to his emotion at the right time and in a proper manner. This means emotional maturity is having proper emotions at proper time and to express in proper from and in proper quality.

\section{Meaning of Emotional Maturity}

Emotional maturity is the characteristic of emotional behaviour that is generally attained by an adult after the expiry of his adolescence period. After attaining emotional maturity, he is able to demonstrate a well- balanced emotional behaviour in his day-to day life. A person may said to be emotionally matures if he has in his possession almost all types of emotions-positive or negative and is able to express them at the appropriate time in an appropriate degree.

Characteristics of an emotionally Matured person

\author{
Dr.M.Soundararajan \\ Associate Professor \\ Department of Education \\ Annamalai University \\ Annamalai Nagar
}

An emotionally matured person demonstrates the following traits and characteristics in his behaviour.

Almost all the emotions can be distinctly seen in him and their pattern of expression can be easily recognized.

Manifestation of emotions is very much refined. Usually he expresses his emotions in a socially desirable way.

He is able exercise control over his emotions. Sudden inappropriate emotional outbursts are rarely found in him. He is able to hide his feelings and check his emotional tide.

The person perceives things in their real perspective. He is not a daydreamer and does not possess the desire to run away from realities.

His intellectual powers like thinking and reasoning are properly exercised by him in making any decision. He is guided more by his intellect than his emotions.

He does not possess the habit of rationalization i e he never argues in defense of his undesirable or improper conduct. Also he never shifts the responsibility of his mistakes on others. He is always honest in his behaviour.

He possesses adequate self-concept and self-respect. He never likes to do things or show such behaviour that can injure his self-respect and is adverse to his ideals.

He is not confined to himself. He thinks about others and is keen to maintain social relationships. He never engages himself in such behaviour as is antisocial and can result in social conflicts and strain his social relationship.

He can exercise his emotions at a proper time in a proper place. If there is a danger to his self-prestige or if anyone is in distress, he can rise to the occasion by exercising his emotion of anger. But if he commits a mistake and is rebuked, he is equally able to check his emotion of anger. Matured emotional behaviour is characterized by greater stability. A person having such maturity does not sudden shift from one emotion to another.

\section{Achievement in Economics}

Economics is the study of how people and societies allocate resources. Economics is the study of how people get the things they want and need and how these things are distributed. Economics is vital Social Science directly related to day to day life. Its concern with is with individual, local and global activities. Therefore, it is taught at school level with a view to strengthen students' understanding of socioeconomic aspects and their roles in the development.

The present context of Globalization, privatization, Liberalization has produced many challenges for all walks of and most of them are in socio-economic concern. Therefore, the knowledge of economics is become essential for the 
peoples in diversified fields. Keeping this view NPE (1986) has recommended to introduce economics as one of the subject for higher secondary school level. Economics is a subject studied from XI standard. Since it is a newly introduced at Higher Secondary level, the factors affecting its achievement are to be considered seriously. One of the factors which contribute much on students' achievement ion subjects is Emotional Maturity.

\section{Need and importance of this study}

It is known that several environmental factors too, influence the pupils' academic achievements. In the normal Indian classroom climate, teachers have to teach students hailing from socio-cultural and economic backgrounds. This naturally leads to a number of problems in instruction, the factors influences teaching and learning process. Higher secondary students are crossing the crucial adolescent period, in this period their study are affected much by their Emotional Maturity, hence the instigator decided to take up this study.

\section{Objectives of the study}

To find out the Emotional Maturity of Higher Secondary students.

To find out the Achievement in Economics of Higher Secondary students.

To find out whether there is any significant difference between the selected pairs of sub samples in respective of Emotional Maturity of higher secondary students.

To find out whether there is any significant difference between the selected pairs of sub samples in respective of Achievement in Economics of higher secondary students.

\section{Method of Study}

The present investigation was undertaken by using normative survey method.

\section{Tool Used}

Emotional Maturity Scale constructed and standardized by K.M.Roma Pal (1984).

\section{Reliability}

The reliability of the adjustment inventory was established by the investigator by using split-half method, which was found to be 0.83 .

\section{Validity}

The investigator also ensured the validity of the tool by using content validity. It means to get opinion from the area experts and experts in Educational Research. The author of the tool also found the construct validity.

Academic achievement Test Questions for Economics Subject prepared by the Investigator was used to get Academic achievement scores.

\section{Statistical Techniques}

In this present investigation the following Statistical techniques were used.

\section{Descriptive Analysis}

Measures of central tendency (Mean)

Measures of variability (Standard Deviation)

Differential Analysis
Independent sample ' $t$ ' test

Sample of the Study

The present study consists of 1060 Higher Secondary Students studying in Tirunelvei district of Tamilnadu State. The sample was selected by using simple random sampling technique. The sample forms a representative sample of the entire population. Due Proportionate weightage was given to various subsamples.

\section{Descriptive and Differential Analysis}

Analysis of Mean and SD scores of Emotional Maturity of the Higher Secondary Students

To find out the Emotional Maturity of Higher Secondary students mean and SD are calculated.

Table No.1

Mean and SD scores of Emotional Maturity of the Higher Secondary Students

\begin{tabular}{|l|l|l|l|}
\hline Sample & N & Mean & SD \\
\hline Entire Sample & 1060 & 136.53 & 24.46 \\
\hline
\end{tabular}

The mean value of Emotional Maturity scores 136.53 indicates that the higher secondary students are having extremely unstable Emotional Maturity.

Analysis of Mean and SD scores of Achievement in Economics of the Higher Secondary Students

To find out the Achievement in Economics of Higher Secondary students mean and SD are calculated.

\section{Table No.2}

Mean and SD scores of Achievement in Economics of the Higher Secondary Students

\begin{tabular}{|l|l|l|l|}
\hline Sample & N & Mean & SD \\
\hline Entire Sample & 1060 & 75.47 & 11.08 \\
\hline
\end{tabular}

The mean value of Achievement in Economics scores $(M=75.47)$ indicates that the higher secondary students are having high Achievement in Economics.

Analysis of Mean and SD scores of Emotional Maturity of the Male and Female Higher Secondary Students

\section{Null hypothesis}

There is no significant difference between Male and Female Higher Secondary students with respect to their Emotional Maturity.

\section{Table No.3}

The Significance of the Difference between the Means of Emotional Maturity Scores of the Male and Female Students

\begin{tabular}{|l|l|l|l|l|l|}
\hline $\begin{array}{l}\text { Sub- } \\
\text { Samples }\end{array}$ & N & Mean & SD & $\begin{array}{l}\text { t- } \\
\text { value }\end{array}$ & $\begin{array}{l}\text { Significance } \\
\text { at } 0.05 \text { level }\end{array}$ \\
\hline Male & 460 & 132.48 & 26.84 & 4.76 & Significant \\
\cline { 1 - 4 } Female & 600 & 139.63 & 21.98 & & \\
\hline
\end{tabular}

From the above table, since the ' $t$ ' value is significant at 0.05 level, the above null hypothesis is rejected and it is concluded that there is significant difference between male and female 
higher secondary school students with respect to their Emotional Maturity.

Analysis of Mean and SD scores of Emotional Maturity of the rural and urban Higher Secondary Students

\section{Null hypothesis}

There is no significant difference between rural and urban Higher Secondary students with respect to their Emotional Maturity.

\section{Table No.4}

The Significance of the Difference between the Means of Emotional Maturity Scores of the rural and urban Students

\begin{tabular}{|l|l|l|l|l|l|}
\hline $\begin{array}{l}\text { Sub- } \\
\text { Samples }\end{array}$ & N & Mean & SD & $\begin{array}{l}\text { t- } \\
\text { value }\end{array}$ & $\begin{array}{l}\text { Significance } \\
\text { at 0.05 level }\end{array}$ \\
\hline Rural & 560 & 135.18 & 26.75 & 1.92 & $\begin{array}{l}\text { Not } \\
\text { significant }\end{array}$ \\
\hline Urban & 500 & 138.04 & 21.52 & & \\
\hline
\end{tabular}

From the above table, since the ' $t$ ' value is significant at 0.05 level, the above null hypothesis is accepted and it is concluded that there is no significant difference between rural and urban Higher Secondary students with respect to their Emotional Maturity.

Analysis of Mean and SD scores of Emotional Maturity of the Government and Aided Higher Secondary Students

\section{Null hypothesis}

There is no significant difference between Government and Aided Higher Secondary School students with respect to their Emotional Maturity.

\section{Table No.5}

The Significance of the Difference between the Means of Emotional Maturity Scores of the Government and Aided Students

\begin{tabular}{|l|l|l|l|l|l|}
\hline $\begin{array}{l}\text { Sub- } \\
\text { Samples }\end{array}$ & N & Mean & SD & $\begin{array}{l}\text { t- } \\
\text { value }\end{array}$ & $\begin{array}{l}\text { Significance } \\
\text { at 0.05 level }\end{array}$ \\
\hline Govt. & 571 & 136.77 & 24.04 & 0.34 & $\begin{array}{l}\text { Not } \\
\text { significant }\end{array}$ \\
\hline Aided & 489 & 136.25 & 24.95 & 0.9 \\
\hline
\end{tabular}

From the above table, since the ' $t$ ' value is not significant at 0.05 level, the above null hypothesis is accepted and it is concluded that there is no significant difference between Government and Aided Higher Secondary students with respect to their Emotional Maturity.

Analysis of Mean and SD scores of Emotional Maturity of the Day scholar and Hostel staying Higher Secondary Students

\section{Null hypothesis}

There is no significant difference between Day scholar and Hostel staying Higher Secondary students with respect to their Emotional Maturity.

\section{Table No.6}

The Significance of the Difference between the Means of Emotional Maturity Scores of the Day scholar and Hostel staying Students

\begin{tabular}{|l|l|l|l|l|l|}
\hline $\begin{array}{l}\text { Sub- } \\
\text { Samples }\end{array}$ & N & Mean & SD & $\begin{array}{l}\text { t- } \\
\text { value }\end{array}$ & $\begin{array}{l}\text { Significance } \\
\text { at } 0.05 \text { level }\end{array}$ \\
\hline $\begin{array}{l}\text { Day } \\
\text { scholar }\end{array}$ & 571 & 132.83 & 25.61 & 2.01 & Significant \\
\cline { 1 - 4 } Hosteller & 489 & 137.15 & 24.22 & & \\
\hline
\end{tabular}

From the above table, since the ' $t$ ' value is significant at 0.05 level, the above null hypothesis is rejected and it is concluded that there is significant difference between Day scholar and Hostel staying Higher Secondary students with respect to their Emotional Maturity.

Analysis of Mean and SD scores of Achievement in Economics of the Male and Female Higher Secondary Students

\section{Null hypothesis}

There is no significant difference between Male and Female Higher Secondary students with respect to their Achievement in Economics.

\section{Table No. 7}

The Significance of the Difference between the Means of Achievement in Economics Scores of the Male and Female Students

\begin{tabular}{|l|l|l|l|l|l|}
\hline $\begin{array}{l}\text { Sub- } \\
\text { Samples }\end{array}$ & N & Mean & SD & $\begin{array}{l}\text { t- } \\
\text { value }\end{array}$ & $\begin{array}{l}\text { Significance } \\
\text { at } 0.05 \text { level }\end{array}$ \\
\hline Male & 460 & 74.53 & 11.22 & 2.43 & Significant \\
\cline { 1 - 3 } Female & 600 & 76.20 & 10.82 & & \\
\hline
\end{tabular}

From the above table, since the ' $t$ ' value is significant at 0.05 level, the above null hypothesis is rejected and it is concluded that there is significant difference between male and female higher secondary school students with respect to their Achievement in Economics.

Analysis of Mean and SD scores of Achievement in Economics of the rural and urban Higher Secondary Students

\section{Null hypothesis}

There is no significant difference between rural and urban Higher Secondary students with respect to their Achievement in Economics.

\section{Table No.8}

The Significance of the Difference between the Means of Achievement in Economics Scores of the rural and urban Students

\begin{tabular}{|l|l|l|l|l|l|}
\hline $\begin{array}{l}\text { Sub- } \\
\text { Samples }\end{array}$ & N & Mean & SD & $\begin{array}{l}\text { t- } \\
\text { value }\end{array}$ & $\begin{array}{l}\text { Significance } \\
\text { at 0.05 level }\end{array}$ \\
\hline Rural & 560 & 75.06 & 11.48 & 1.29 & $\begin{array}{l}\text { Not } \\
\text { significant }\end{array}$ \\
\hline Urban & 500 & 75.93 & 10.48 & 1.90 \\
\hline
\end{tabular}

From the above table, since the ' $t$ ' value is not significant at 0.05 level, the above null hypothesis is accepted and it is concluded that there is no significant difference between rural and urban Higher Secondary students with respect to their Achievement in Economics.

Analysis of Mean and SD scores of Achievement in Economics of the Government and Aided Higher Secondary Students

\section{Null hypothesis}


There is no significant difference between Government and Aided Higher Secondary School students with respect to their Achievement in Economics.

\section{Table No.8}

The Significance of the Difference between the Means of Achievement in Economics Scores of the Government and Aided Students

\begin{tabular}{|l|l|l|l|l|l|}
\hline $\begin{array}{l}\text { Sub- } \\
\text { Samples }\end{array}$ & N & Mean & SD & $\begin{array}{l}\text { t- } \\
\text { value }\end{array}$ & $\begin{array}{l}\text { Significance } \\
\text { at } 0.05 \text { level }\end{array}$ \\
\hline Govt. & 571 & 75.82 & 11.07 & 1.02 & $\begin{array}{l}\text { Not } \\
\text { significant }\end{array}$ \\
\hline Aided & 489 & 75.06 & 10.97 & & \\
\hline
\end{tabular}

From the above table, since the ' $t$ ' value is not significant at 0.05 level, the above null hypothesis is accepted and it is concluded that there is no significant difference between Government and Aided Higher Secondary students with respect to their Achievement in Economics.

Analysis of Mean and SD scores of Achievement in Economics of the Day scholar and Hostel staying Higher Secondary Students

\section{Null hypothesis}

There is no significant difference between Day scholar and Hostel staying Higher Secondary students with respect to their Achievement in Economics.

\section{Table No.9}

The Significance of the Difference between the Means of Achievement in Economics Scores of the Day scholar and Hostel staying Students

\begin{tabular}{|l|l|l|l|l|l|}
\hline $\begin{array}{l}\text { Sub- } \\
\text { Samples }\end{array}$ & N & Mean & SD & $\begin{array}{l}\text { t- } \\
\text { value }\end{array}$ & $\begin{array}{l}\text { Significance } \\
\text { at } 0.05 \text { level }\end{array}$ \\
\hline $\begin{array}{l}\text { Day } \\
\text { scholar }\end{array}$ & 152 & 74.56 & 10.95 & 1.09 & $\begin{array}{l}\text { Not } \\
\text { significant }\end{array}$ \\
\hline Hosteller & 908 & 75.62 & 11.03 & & \\
\hline
\end{tabular}

From the above table, since the ' $t$ ' value is significant at 0.05 level, the above null hypothesis is accepted and it is concluded that there is no significant difference between Day scholar and Hostel staying Higher Secondary students with respect to their Achievement in Economics.

\section{Findings of the Study}

The mean value of Emotional Maturity scores $(M=136.53)$ indicates that the higher secondary students are having extremely unstable Emotional Maturity.

The mean value of Achievement in Economics scores $(\mathrm{M}=75.47))$ indicates that the higher secondary students are having high Achievement in Economics.

There is significant difference between male and female higher secondary students with respect to level of Emotional Maturity.

There is no significant difference between rural and urban Higher Secondary students with respect to their Emotional Maturity.

There is no significant difference between Government and Aided Higher Secondary students with respect to their Emotional Maturity.
There is significant difference between Day scholar and Hostel staying Higher Secondary students with respect to their Emotional Maturity.

There is significant difference between male and female higher secondary students with respect to level of Achievement in Economics.

There is no significant difference between rural and urban Higher Secondary students with respect to their Achievement in Economics.

There is no significant difference between Government and Aided Higher Secondary students with respect to their Achievement in Economics.

There is no significant difference between Day scholar and Hostel staying Higher Secondary students with respect to their Achievement in Economics.

\section{Recommendations}

The result of this study shows that higher secondary students are having extremely unstable Emotional Maturity. Hence, to stabilize and to increase their Emotional, efforts are to be taken by the parents and Teachers.

There is significant difference between male and female, Day scholar and Hosteller higher secondary school students with respect to their Emotional Maturity from these results it is evident that these variables are influencing higher secondary students Emotional Maturity. Hence, these variables need to be considered by the Parents and Teachers. There is no significant difference between Government Aided Higher Secondary school students and rural and urban resised students with respect to their Emotional Maturity.

Hence, Causes for the differences are to be studied and the negative causes should be eliminated to increase Emotional Maturity among the higher secondary students. Teachers should inculcate their parents to Plan to provide a good environment to their children.

The result of this study shows that higher secondary students are having high Achievement in Economics. Hence, to sustain and to increase the quality, efforts are to be taken by the parents.

There is significant difference between male and female, higher secondary school students, with respect to their high Achievement in Economics. From this, it is evident that gender influences higher secondary students' Achievement in Economics. Hence, gender difference should be considered while framing the methodology for teaching Economics. There is no significant difference between rural and urban Government and Aided Higher Secondary school students and Day scholar and Hostel staying students with respect to their Achievement in Economics. From these results it is evident that these variables are not influencing higher secondary students' high Achievement in Economics. Hence, Causes for the differences are to be studied and the negative causes should be eliminated to increase high Achievement in Economics among the higher secondary students. Teachers should inculcate their parents to Plan to provide a good environment to their children.

\section{CONCLUSION:}

This study shows the nature of Emotional Maturity and Achievement in Economics of higher secondary students in Tirunelveli district students. Further this study reveals the differences in influence by the demography of the students. 
To sustain and to increase good Emotional Maturity and achievement in Economics, special concern is to be extended by the Parents. Parents should be met by the teachers frequently report about students' positives and negatives and needs.

\section{REFERENCES:}

[1] Geeta S. Pastey and Vijayalaxmi A. Aminbhavi (2006) Impact of Emotional Maturity on Stress and Self Cofidence of Adolescents, Journal of the Indian Academy of Applied Psychology, January 2006, Vol. 32, No.1, 66-70.

[2] Jadhav, N. S. (2010) Relationship between Home Environment \& Emotional Maturity of College Going Students of Belgaum District, International Research Journal, VOL I, 13, 34-36.

[3] Landau, Erika and Weissler, Kineret (1998) The Relationship between Emotional Maturity, Intelligence and Creativity in Gifted Children. Gifted Education International, v13 n2 p100-105.

[4] Phillip Klever (2009) Goal Direction and Effectiveness, Emotional Maturity, and Nuclear Family Functioning, Journal of Marital and Family Therapy, Vol $35,3,308-324$.

[5] Hiremani, S. G., Khadi, P. B., Gaonkar, V. and Katarki, P. A., 1994, Comparison of emotional maturity and adjustment of destitute and normal adolescent girls. Ind.. Psych. Rev., 42 (3-4) 6-11.

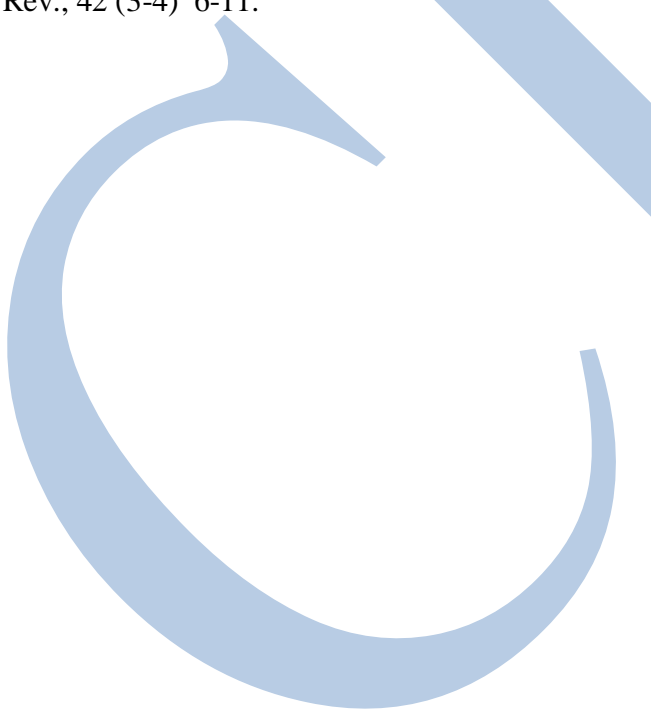

